\title{
New Technology, a Catalyst for the Developmental Power Steering of Modern Built Environment in South-West Nigeria: An Overview
}

\author{
Aremu, P.S.0.1 \\ Makinde, D.0.2 \\ Olawunni; P.O. ${ }^{3}$ \\ 123 Department of Urban and Regional Planning \\ Obafemi Awolowo University, Ile-Ife. Nigeria \\ 1Psoaremu1975@gmail.com
}

Doi:10.5901/mjss.2013.v4n3p723

\begin{abstract}
Man's search for a good thing of life could be taken as the driving force behind the developmental attitude of his built environment, for this simple reason, the physical development of his environment has been and will always be evolving. In the South-Western part of Nigeria, as in other parts of the world, architecture, urban planning as well as the contribution of art, like in other areas of a human life evolved from the host culture before the arrival of the external influences or interference. That is to say that the past is in the present in all human endeavours, supported by the new technology, which paved way for the development of most human undertakings. Traditional built environment and architecture, which were formerly unalloyed before the arrival of the new civilization, and technology a few centuries ago suffered some rapes from external influences. These influences vary in their so-called negative or positive contributions to human existence in South-Western Nigeria. Most of these contributions are in form of materials, styles and design of building structures. As years rolled by, many of these influences and contributions became more and more noticeable, while the former cherished traditional elements reduced visibly in Southwestern part of Nigeria. The industrial revolution of the 1900s swept across the western world heralding technological breakthrough and registered a great mark, South-Western Nigeria was not left behind in the scheme of things. This contributed in no small measure to the new phase of architecture, design and built environment, which this paper deals with. The paper also pinpoints some towns and cities which witnessed changes in the study area. It also highlights the benefits of this new technological break through.
\end{abstract}

Keywords: Technology, built environment, architecture, influences, industrial revolution, urban planning.

\section{Introduction}

Changes in African architecture and built environment generally, have been very gradual. A significant change in architecture, designs and styles in the built environment has been visible from 1900s. It could be asserted that major changes only started when the European started seeking for a place to buy raw materials and sell their finished products. They started building roads to link the Urban and Rural centers for easy transportation of their products. Western ideas began to mix up with the traditional relevance and things began to fall apart traditionally; the trado-cultural norms could no longer hold themselves firmly together as before. The continent of Africa generally embraced the new culture and technology with the freedom that they allowed. What is a built environment? Many writers have supplied different definitions but all of them points to the same place.

Among the growing number of definitions of what built environment means are www.m.wisegeek.com/what-is-abuilt environment. www.uwindsor.ca.vabe/builtenvironment and www.gooduniguide.com.au/school-leavers/fields-of-study /builtenvironment. All of them agree that built environment is a man-made structure and infrastructure as opposed to a part of the natural environment. They equally add that built-environment is interdisciplinary in nature. The above clearly indicates that apart from architecture, built environment also includes other disciplines such as visual art, urban planning, engineering, interior and exterior design, history etc.

In like vein, built environment includes all structures created by people including infrastructures like streets, sidewalks, electricity, air and sea ports, parks, stadia, public and private places, gardens etc. All these are mostly found in cities and towns such as Lagos (the former capital of Nigeria), Ibadan, Abeokuta, Akure, Ondo, Ogbomoso, Oyo and 
other big torms and cities in the study areas. These infrastructures are sometimes decorated with art works to enhance beauty. To achieve all these, human behaviour experts (artists, decorators, city and town planners, architects, surveyors etc) work together to discover the most positive use of space to be in line with good living. In most towns and cities mentioned in the study area, population growth is a menace, which to individuals and governments should plan for by creating a conducive and accommodating environment for the welfare of their people.

Historical trends from the traditional periods revealed that each community within its available materials exerts efforts on improving its environment to meet the demands of its people. This accounts for the development of towns and cities to meet the present standard of living. It is interesting to add that South-Western Nigeria has since joined other parts of the country to witness remarkable changes in architecture and built environment in gradual progression since 1900s. This has created gradual diversion from traditional to neo-traditional then to a more foreign based environment because of the contacts and influences received and imbibed.

This paper tries to survey overview influences on architecture and built environment to include the relevance of art in the study area. It equally captures the visible changes as a result of technological innovations. Amole and Okpako (2005) rightly suggest that one of the forces behind globalization is technological innovation, which has supplied infrastructure by trans-world connections. The modern built environment in the study area is therefore the product of technological advancement designed to meet the demands of modern time. It is therefore pertinent to add that the demands of the governments for a better environment for its people, eventually led to the establishment of Urban and Regional Planning and Town Planning Centers in the study area. The use of bill boards as a means of advertisement of products and events etc is an added advantage to the beautification of our built environment. To capture the essence, the paper categorises its finding into four thus: Human Development areas (Presidential Buildings); modern markets, Recreation areas, electricity, Roads and Streets.

\section{Human Dwellings (Residential Buildings)}

Human dwellings in the study area, most especially in Lagos, Ibadan, Akure and Abeokuta, went through physical changes, the changes created by colonial administrators and missionaries etc. They left a permanent architectural mark all over where they lived. This ranged from housing to churches, to office buildings. Technology has made possible the construction of different types of buildings. The type of building constructed is majorly determined by its function, therefore the style and construction process of building differ. The structure and aesthetics of each building and their environment is the product of new technological innovations. The use of new building materials as a result of technological advancement is worth observing. The introduction of materials such as cement blocks, burnt bricks, corrugated iron sheets of different types and sizes, wrought iron, adex, glass etc are very commonly used in most towns and cities. Amole and Okpako (2005) further observe that new available materials facilitated by easy movement of good and ideas, freed architecture from restrictions of building with inferior materials. Usage of new materials, innovations, and new possibilities came up, thus the introduction of storey buildings, sky scrapers and other amenities. Building forms part of the most important aspects of the built environment. Technology directly affected architecture by facilitating the creation of new materials with which to build. The new materials were formerly too expensive, mass-produced and flexible to use. Thus technology transformed architecture into a tool for social and cultural reform. With this new technology new materials for building construction were introduced, and new designs came into being. Because of this reason, building construction has recorded a lot of fundamental changes, which gave a new look to the built environment. The structures as well as the interiors of dwelling places wear a new look. We now have sections that answer the call of human needs. The urban design has enabled people to now live in estates with well organized system. Visual art has equally contributed immensely to built environment, human dwelling is an example of this. It is used to beautify the entire environment most especially when paintings, sculptural works and ceramic wares are used as decorative emblems in the interiors of buildings. Murals and mosaics are also used on walls.

Human intellect, social interactions and knowledge of technology acquired by the people in this area, and aesthetic creativity have also played and still playing a major role in the continuous improvement on the residential building designs. It is also discovered that their architectural structures are determined by natural geographical and climatic conditions of the study area. The Yoruba people occupy about ninety-nine percent of the area. According to Eneh and Ati (2010) traditionally, they are characterized by large social segregation as evidenced by such cities as Lagos, Ibadan, Abeokuta etc. In the distant past, Yoruba indigenous architecture was without embellishments but simply earth plastered, representing a monolithic appearance. They used to make frame construction, beams, brackets for carrying the roofs before the advent of the new technology. As the taste of man changes sporadically, he seeks to befit his status partly by 
the nature of the architectural embellishment and the location of his house. The builders, in expanding and promoting the built environment and social status of the owner, introduce new decorative forms such as aluminum roof sheets, glass windows, and creatively designed railings for balconies. Introduction of interior designs including, decorated arches around the doors and windows. In addition to these new innovations, paints of different colours and textures equally came into the scene of aesthetics. Generally, there has been a drift or shift in the traditional residential buildings as a result of the introduction of new materials as mentioned above. The shift created by forward looking builders, architects and planners.

South-Western Nigeria is considered to be the most developed area of the country, the area that first embraced the new technology because of their early contact with the Europeans. Modern Nigeria architecture and built environment metamorphosed from two basic influences viz: The introduction of Afro-Brazilian type of building into the area of study (see Plate 1) by the returnee ex-slaves, from America and colonization. The impact of ex-returnee slaves was greatly felt in the area of study most especially in big cities and towns like Lagos and Abeokuta, the areas very close to the coast. Before 1900s each ethnic group in the traditional society could be identified with its own communally designed residential buildings based on available materials within each geographical location and climatic condition. Formerly, each building within the built environment in the traditional society was an object of pride and a means of identity. Most traditional residential buildings in Lagos, Ibadan, Abeokuta, Akure etc were initially designed and built by local builders without adequate planning. The contacts with foreign culture have brought about influences on virtually every aspect of life in the study area, ranging from religion to politics, socio-cultural life, architecture and built environment all of which have not been static but changing as a result of contact with education, tourism, economic activities, technology and other forms of expository channels. In most of these towns and cities in the study area, traditional buildings are giving way to dominating modern residential buildings with their imposing aesthetic and functional values. Jáafar (2010) observes that even the royal palaces (such seen in Lagos, ljebu-Ode, Abeokuta etc) once epitomes of the old-style residential buildings, are now changing their look.

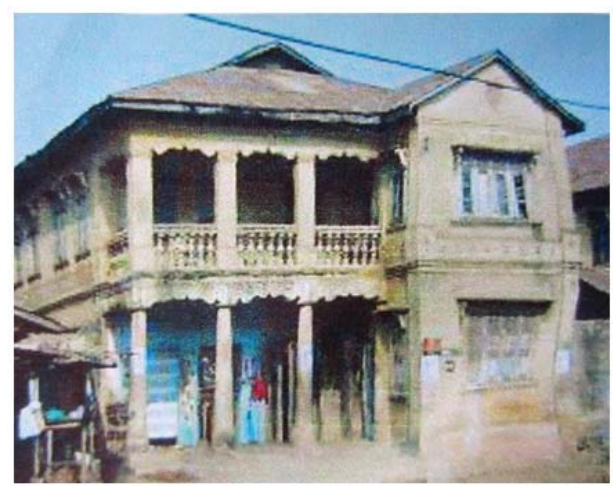

Plate 1: Afro-Brazilian type building

Instructively, most traditional fences around kings palaces are now being replaced with modern structures. Landscape is not left out of these innovations. Landscaping of the surrounding and the exterior of the built environment is decorated with beautiful flowers and grasses to honour and promote kingship system in the study area.

In the past, surroundings of kings' palaces were not adequately given attention to simply because of limited building materials available. Availability of modern building materials and equipment for construction greatly contribute to the aesthetic upliftment of the environment. The building walls and fences are now built with cement blocks and also plastered with cement, glass windows in the form louvres and aluminum framed security doors, pipe borne water from bore holes and wells are now being added to take care of the needs of house owners. All these are new attributes of good living.

\section{Modern Markets, Recreation Area, Electricity and Streets}

In treating the above issues, one must put into considerations the relevance of urban design which involves the planning of the cities and towns in the study area; it also entails mapping out and allotting layout for development. It is interesting to note that a well planned environment will free the cities and towns from congestion and will allow for even distribution 
of social and economic activities and amenities. This will take care of where markets and recreation centers should be. In Lagos, Abeokuta, Ibadan and other big towns such as Oshogbo, Ogbomoso, Oyo, lle-lfe etc, there is a public outcry in some sectors against the destruction of private buildings to pave way for modern streets constructions, markets, shopping complexies, recreation areas or buildings. Traditional family buildings are being destroyed to give room for decent and world acclaimed structures.

In all the cities and some big towns in the study area, the catalyst that brought about new technology was the bilateral relationship and technical partnership with the foreigners (the white people). The wealthy individuals are equally pulling down old structures so as to erect shopping centers and markets. These are some of the materials imported by the British Colonial Government in Nigeria from Britain a few centuries ago; cement, slate roofing, tiles, corrugated roofing sheets, processed wood, synthetic paints among others. These materials were some of the products of technology that changed the field of architecture and built environment. Blier (1998) also made reference to this in her book, The Royal Art of Africa: The Majesty of Form, where she expressed that in modern times, cement and corrugated iron have replaced local materials and construction method. The new technology has wholly transformed architecture, town planning and the artistic contribution, in terms of decoration into a tool for social and cultural reform. We now have modern markets, good tarred roads and recreation centers all created to satisfy the people in the study area. It would be observed that technology directly affect architecture by facilitating the creation of new materials with which to build and construct built environment. These new materials and equipment have given a wide range of possibilities and opportunities which put an end to some engineering limitations of the past and equally allowed for new rational designs based on what the building is meant to be used for.

The products of technology have become integral part of modern society in most cities and towns in SouthWestern part of Nigeria. This has created a new relationship between man and newly introduced machines. What actually help the spread the new innovations is education, education that has a long history in the area. It could be said without an aota of doubt that education entered Nigeria through the area of study, this is why the area is well developed in many ways of human endeavour.

Modern markets are built in towns and cities such as Lagos, Abeokuta, Ibadan where commercial activities strive to accommodate pressure on existing markets. These new markets contain many improved forms of shops which are allocated to individual traders who can afford them. For example, the popular Tejuosho market in Yaba, Lagos is undergoing a reconstruction to standard. This modern market will take care of many traders and even corporate bodies like banks and insurance companies etc. There are new markets in Abeokuta and Ogbomoso that are newly constructed and in the process of allocation.

In most cities and towns in the study area, roads and streets are being constructed on a daily basis. Modern road construction is a product of technology advancement. In Lagos, Ibadan and other big cities and towns, fly-overs are predominant. Major streets and road in the study area are well planned with grasses and flowers planted to represent a beautifully decorated landscape along the sides (see Plate 2). Bridges have also been constructed (see Plate 3). Their aesthetic relevance has added value to the city most especially in Lagos and Abeokuta. In Ibadan, the government has just constructed a fly-over at Makola area of the city to ease and solve vehicle congestion, which is always a problem to motorists. Apart from solving congestion, it equally beautifies the area.

Plate 2: Road Network

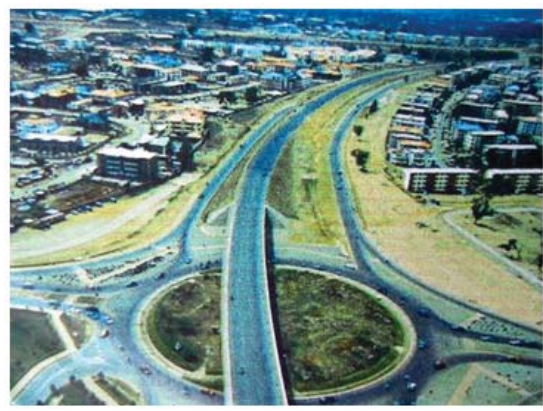




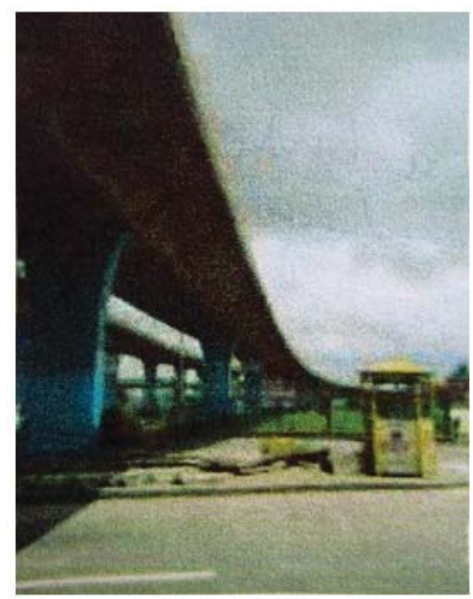

Plate 3: a Bridge in Lagos

There are such in most places in Nigeria as a whole. Technology is spreading like forest fire during the harmattan season and the effect is being felt in all aspects of our lives today. This has also affected recreation and sport areas in the study area, where relaxation centres dot most areas in cities and towns. People go there to relax with friends and families after their daily activities. This is a new and borrowed innovation from the western world.

In cities and big towns today, recreation arena as well as sport centers play an important role in socio-cultural and economic development of people and nations. This new innovation is giving the people most especially the youths and lovers of pleasure that healthy belonging of the built environment. Presently, there is virtually no State in Nigeria without a stadium Complex. Lagos has the first National Stadium sited in Surulere. This built environment has a befitting structure that is adding value to the general outlook of the area.

Rivers are dammed to provide water and electricity for the entire populace. For the economic activities to be successful, electricity, the major determinant of virtually all economic and social activities, should be put in place. These are structures that are parts of the built environment and could be regarded as the carriers of social services. This also involves that building of masts (see Plate 4) in many parts of the study area, now adds to the socio-economic demand of the population.

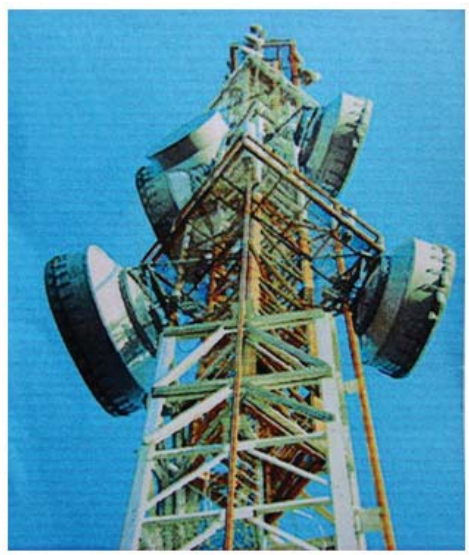

Plate 4: Telecom Mast in Abeokuta

Aside of this, there are series of public sculptures erected in important centers either to tell stories or to promote an individual in the society. 


\section{Conclusion}

In conclusion, it could now be said that the synthesis of science and technology which showed its face as from the time of industrial revolution is without any doubt the most contributory and fundamental element of architectural development today. The effect of this is felt in most countries of the world, the study area of Nigeria is not left behind in the scheme of things. The effect has led to the discovery and manufacturing of materials and equipment for goods and services. They have equally helped to shape the built environment in most cities and towns in South-Western Nigeria.

It is pertinent to conclude that the new technology has not only affected our former built environment through architecture, road construction and other physical construction alone, it has equally eaten deep into services delivery. The future would definitely bring further innovations that would help improve and create new avenues for further developments in the area of study.

\section{References}

Amole, B., Okpako, J. (2005), Globalization, Modernity and Architecture: Modern Architecture in Ibadan after 1960 Globalization, Culture and the Nigerian Built Environment, Vol. 1, ed., Fadare W. et al.

Amole, B., Okpako, J. (opt cit).

Blier, S.P. (1998) The Royal Art of Africa: The Majesty of Form. Harry N. Abrams Mc. New York, p. 128.

Eneh, A.E.O., Ati, O.F. (2006) Composite Materials and Their Uses; A Review. An Unpublished text paper.

Jáafar, J., Abdullahi, B.Y., (2010) In Kano, traditional Architecture is vanishing. Abuja, Weekly Trust Report, 26th June, 2010.

www.gooduniguide.com.av/school-leavers/field-of-study-/built_environment

www.m.wisegeek.com/what-is-a-built-environment. Retrieved Dec. 5th, 2010.

www.uwindsor.ca/vabe/built-environment. 